\title{
Spanish sport facilities: differences between public and private, and according to their business model \\ Las instalaciones deportivas en España: diferencias entre públicas y privadas, y según su modelo de negocio \\ *Jose Antonio Santacruz Lozano, **María Espada Mateos, *Angel Clemente Remón, *José Emilio Jiménez-Beatty Navarro \\ *Universidad de Alcalá (España), **Universidad Politécnica de Madrid (España)
}

\begin{abstract}
Spain boasts numerous multipurpose sports facilities offering a wide range of services. The goal of this study is to ascertain possible differences in management variables or indicators across sports facilities according to whether they are publicly or privately owned and according to business model (administrative license, non-low-cost private, or low-cost private). The universe of study were 4435 Spanish sports facilities (IHRSA, 2016). The represetative sample that participated in the study was 384 sports facilities. Data was gathered by means of face-to-face interviews with sports facilities managers. The results show significant differences for most of the variables analysed (surface area, number of users, income from quotas, extraordinary income, total income, monthly income per customer and average monthly quota) between public and private sports facilities and between business models. The study provides relevant information for people are working in the management of sports facilities, since it allows them to perform benchmark and know what are their points of improvement in the management of sports facilities depending on their ownership and its business model.
\end{abstract}

Key words: sports management, business administration, sports marketing.

Resumen. España cuenta con un gran número de instalaciones deportivas polivalentes que ofrecen una amplia gama de servicios. El objetivo de este estudio es determinar las posibles diferencias en las variables o indicadores de gestión en las instalaciones deportivas según sean de propiedad pública o privada y según el modelo de negocio (concesión administrativa, privados low cost y privados no low cost). El universo de estudio fueron 4435 instalaciones deportivas españolas (IHRSA, 2016). La muestra representativa del estudio fue de 384 instalaciones deportivas. Los datos e información fueron recogidos mediante entrevistas personales con los directores de las instalaciones deportivas. Los resultados muestran diferencias significativas en la mayoría de las variables analizadas (metros cuadrados, número de usuarios, ingresos por cuotas, ingresos extraordinarios, ingresos totales, ingresos mensuales por cliente y cuota mensual promedio) entre instalaciones deportivas públicas y privadas, y entre modelos de negocio. El estudio aporta información relevante para las personas dedicadas a la organización y gestión de las instalaciones deportivas, ya que permite tener puntos de referencia en indicadores de gestión de las instalaciones deportivas y conocer los puntos de mejora según sea la propiedad y el modelo de negocio.

Palabras clave: gestión deportiva, administración de empresas, marketing deportivo.

\section{Introduction}

Over the last few decades, an increasing number of Spaniards have taken up physical activities or sport (García \& Llopis, 2005, 2010; Ministry of Education, Culture and Sport, 2015). In $2015,46.2 \%$ of the Spanish population over the age of 15 took part in some physical or sporting activity at least once a week, according to the Sporting Habits in Spain Survey (Ministry of Education, Culture and Sport, 2015). In some parts of Spain such as the Basque Country, that rate of physical or sporting activity rises as high as $64 \%$ (Sociological Research Office of the Basque Government, 2017). Both studies show that men do more physical activity and sport than women. According to the Sporting Habits in Spain Survey, $50.2 \%$ of men do some physical activity or sport compared with $42.1 \%$ of women, while the Basque Government's study registers figures of $70 \%$ for men as against $57 \%$ for women. The rate of sporting activity also diminishes as a function of age, with figures of $76.1 \%$ for the 15-24-year age-group, 53.2\% for the 25-54-year age-group, and $26 \%$ for the over-55s (Ministry of Education, Culture and Sport, 2015).

When analysing the place people prefer to carry out physical activity of sport, sports facilities is taken to mean a place for collective use which has been built of adapted to

Fecha recepción: 23-10-19. Fecha de aceptación: 06-05-20 Jose Antonio Santacruz Lozano

jose.santacruz@uah.es enable physical or sporting activity to be carried out on a permanent basis, or which is generally acknowledged to enable the performance of such activity. Sports facilities, or sports spaces are spaces where physical activity is carried out (García \& Llopis, 2011). These include sports courts, fitness rooms, swimming pools, rooms for group activities, tennis or paddle tennis courts, and so on.

The logical use of sports facilities for physical activity is confirmed in many studies. In its Sporting Habits in Spain Survey (Ministry of Education, Culture and Sport, 2015) reported that $23.1 \%$ of those taking part in physical activity or sports do so in private gymnasiums; $13.2 \%$ in public gymnasiums, $12.1 \%$ in private sports clubs; and $17.9 \%$ in public multisport centres. In the Basque Country study mentioned earlier, $58 \%$ of those who habitually take part in physical activity or sports are members of a sports facilities or sports club, with $39 \%$ of them using public sports facilities, $24 \%$ sports clubs, and $13 \%$ private sports facilities.

Some research indicated that for some population groups, the offer, access and availability of sports facilities are factors with a direct influence on their rates of physical or sporting activity (Giles-Corti \& Donovan, 2003; Li, Fisher, Brownson \& Bosworth, 2005; Pascual, Regidor, Astasio, Ortega, Navarro \& Domínguez, 2007; Stahl, et al., 2001; Van Lenthe, Brug $\&$ Mackenbach, 2005). Another study in Spain also indicated that sporting activity increases when people are aware that there are sports facilities or outdoor exercise areas near their normal place of residence (Orzanco-Garralda, Guillén, Sainz, 
Redín, De la Rosa \& Aguinaga-Ontoso, 2006).

As for recent trends in Spain's sports facilities sector, until the 1990s, the vast majority of centres not devoted to organised competitive sport, as well as those owned publicly, were family-run gymnasiums or often gymnasiums for bodybuilding and weight-training managed by small businesses (De la Cámara, 2015). It was only in the late 1990s and early 200s that Spain's sports facilities sector was transformed with the construction of sports facilities of greater size with multipurpose spaces catering for various activities: fitness rooms, swimming pools, rooms for monitored activities, and so on. At the same time, those sports facilities offered a new range of physical activity and sports services and a new range of monitored activities, as well as personal training services, sports consultancy, and ancillary or tailored spaces offering complementary services like hairdressing and aesthetics, nutrition, physiotherapy, relaxation areas, carparks or cafés, among others, all of which fomented social relations and the use of other services in addition to those related to physical activity or sport themselves (Dorado, 2006). This kind of sports facilities were built both publicly and privately, and still coexist in the market today. It was also around the late 1990s early 2000s that the Spanish administration began to introduce the system of administrative licenses in public sports facilities, whereby funding, control and supervision were in public hands, but management was private, as laid down in Law 30/2007 (30 October), regarding Public Sector Contracts. This law provides for licenses in the framework of the public service management contract, as set out in article 253, whose scope of application is stipulated in article 251 with the proviso that «under no circumstances shall there be provision by indirect management of services entailing the exercise of the powers inherent to the public authorities».

From 2009, the low-cost concept arrived in Spain's sports facilities sector, which amounted to monthly fees for using the services offered of around 20 euros per month. A significant number or sports facilities were opened in this segment (De la Cámara, 2015), which followed the lead of other low-cost segments in the textile or airline sectors, present in Spain since some years earlier. This segment bases its competitive advantage on offering unbeatable prices, which, according to Porter (2009) are, together with specialisation and differentiation, one of the three routes to corporate success. Thus, companies in Spain's sports facilities sector adopted this segment's strategies as identified by Algar (2012). These include prices 50\% lower than in conventional gyms or sports facilities; the use of technology; a basic, no-frills gym service; extended opening hours; whittling down to a minimum the human resources required for service provision; and the implantation of the self-service philosophy. In most sectors of the economy, the low-cost business model has impacted customer behaviour and led to a sea-change in the perception of marketing in that customers are clearer about the type of service and product they are seeking, its format, the price they are willing to pay and even the means of payment they prefer (Valls, 2010), while it is the companies which have to adapt to the characteristics and needs of their customers. As far as the fitness sector in sports facilities is concerned, some studies showed that low-cost centres are preferred more by man than women on account of the type of spaces and services they provide (Águila, Sicilia, Muyor \& Orta, 2009; Barros \& Gonçalves, 2009; García, Cepeda \& Martín, 2012; Martínez \& Martínez, 2010; Tsitskari \& Tsitskari, 2013), others that low-cost sports facilities are preferred by women (Hsueh \& Su, 2013; Ulseth, 2004), and yet others suggesting there is barely any difference between the sexes (Rial, Varela, Rial \& Real, 2010). Nevertheless, HaroGonzález, Pérez-Ordas, Leyton-Román, Caamaño-Guadix and Nuviala (2018) observed there are two groups of women clients of sports centers: women with high self-determined motivation who go to exclusive female sports centers, and a second group with low levels of self-determined motivation, who go to mixed sports centers.

There is greater agreement in the literature regarding age, is so far as most members of low-cost sports facilities are aged between 16 and 40 (García \& Llopis, 2011; Hsueh \& Su, 2013; Tsitskari \& Tsitskari, 2013). In short, the Spanish sports facilities sector (excluding centres devoted to organised competitive sport) is home to various types and models of sports facilities including public sports facilities operating under administrative license, private, low-cost sports facilities, and private non-low-cost centres.

As far as the typology of Spain's sports facilities is concerned, according to the IHRSA's Global Report for 2017 (International Health Racquet Sports Association, 2017), Spain boasts 4485 sports facilities, both public and private, and is the fourth country in Europe with most such centres, preceded by Germany, Italy and Great Britain. In relation to fitness trends in Spain, The National Survey of Trends in Spain 2018 established as main trends the qualification and professional experience of the staff, functional training, exercise and weight loss, high intensity interval training, personal training, bodyweight training, monitoring results and exercise apps for smartphones (Veiga, Valcarce, King \& De la Cámara, 2018). About the trend of smartphone apps use, it seems to produce positive effects in the practice of physical activity and weight loss, which positively affects the health of users (Aznar, Cáceres, Trujillo \& Romero, 2019).

The 2019 survey offered results similar to those of 2018, but highlights the entry among the main fitness trends: professional regulation of workers in the fitness sector and fitness programs for older adults (Veiga, Valcarce-Torrente, King \& De la Cámara, 2019). The investigations by EstradaMarcén, Sanz, Casterad, Simón and Roso (2019) and García and Froment (2018) reaffirm these trends. For 2020, strength training is the main trend in Spain; and the trend of multidisciplinary work teams (doctors, physiotherapists, Sports Science graduates and nutritionists) appears in third place. (De la Cámara, Valcarce-Torrente \& Veiga, 2020).

This paper studies the possible differences between sports facilities according to their ownership (public or private), according to business model (administrative license, private low-cost, and private non-low-cost). Therefore, sports facilities have been categorised according to the price of services offered and the ownership variable. Magretta (2002) took business model to mean «explanatory accounts of how the business works». Chesbrough and Rosenbloom (2001) offered a more detailed and useful definition which identifies the functions of a business model as: formulating a value 
proposition, identifying a market segment, defining the structure of the value chain; estimating the cost structure and the profit potential; and defining the company's position in the value network and devising the competitive strategy. Osterwalder, Pigneur and Tucci (2005) review various definitions before providing their own: a business model is the description of the value that a company offers one or several customer segments and of the company's architecture and of its network of partners, in order to create, commercialise and contribute that value, while also generating profitable and sustainable income flow. This definition therefore specifies 9 elements of a business model: value proposition, target customer, distribution channel, relations, configuration of value chain, essential competencies, partnership network, cost structure and incomes model.

With respect to Spain's sports facilities sector, various studies have tackled the differences that exist depending on the type of owner or the business model of the sports facilities. Martínez-Tur, González, Ramos, Tordera, Peiró and Rodríguez (1995) identified five types of sports facilities: publicly-run public sports facilities; publicly or privatelyrun public sports facilities; private commercial sports facilities; private cooperative sports facilities run by sports clubs or non-profit associations; and restricted-use sports facilities (for a particular type of target customer, such as tennis clubs); they added that in order to classify Spain's sports facilities, it was not enough to distinguish between them solely on the basis of public or private ownership. Gambau (2002) also tackled this issue and claimed that the actors involved in sports service provision may be categorised into three sectors: the public sector, the profit-making private sector, and the non-profit private sector. A recent study has classified sports facilities according to the prices of the services they provide and the form of ownership. Their categories are: public, private, low-cost and sessional sports facilities (Cereijo, Gullón, Cebrecos, Bilal, Santacruz, Badland \& Franco, 2019) This research divides private sports facilities according to the monthly price of their services. It establishes a category for low-cost sports facilities that are priced less than 30 euros per month and another category for private sports facilities above 30 euros per month.

As for selecting indicators for analysis, Kaplan and Norton (2008) identified four perspectives which make up the balanced scorecard (BSC) organisations use to help them ascertain their current situation. The perspectives from which the indicators to be measured derive are the customer/ stakeholder, the financial, the internal process, and the learning and growth perspectives. In relation to the sports organisations and companies sector, Alberto, Hernando and Fernández (1996) dealt with the indicators within the control techniques they recommended for a sports organisation and established six blocks for an organisation's internal-external control: the staff block (for example, the cost of personnel as a function of the work done); centres block (monthly inventory user control and maintenance, among others); economic-financial block (for example, the monthly performance of each service area or centre bookings); purchases block (amount of purchases from suppliers); sports services block (number of members for each services, hours of weekly service, receipts per service); and others (for example, the evolution of the local population pyramid). Carrasco, Buendía, Navarro, Valencia and Llorente (2006) devised a group of public sports facilities management indicators intended to evaluate the efficiency of public sports services and proposed 4 indicator dimensions: activity indicators (including the area of the sports facilities and the total number of members); financial indicators (including cost per user per sports service); local indicators (such as user ages, educational level, unemployment rate, etc.). París (2003) proposed two types of indicator classification: quantitative indicators (where the baseline is a certain quantity, percentage or number) and qualitative indicators (positions to be reached or maintained, prizes or challenges to achieve). On the other hand, he proposed the classification of sports organisation indicators according to their type, for which he defines seven indicator categories. This classification considers centrerelated indicators (for example, form of management); inputrelated indicators (for example, staff numbers, work absenteeism, labour cost per hour); activity-related indicators (such as number of people using each activity); resultsrelated indicators (for example receipts from activities, installation or activity costs, and income per user; service demand-related indicators (such as sex or age of members); service supply-related indicators (weekly opening hours, number of hours per service provided, fee or quota for centres or services, and so on); and final impact-related indicators (such as total number of members, percentage of use or participation, fall in number of complaints). Carrasco (2012) established costs as one of the main management indicators in public services. The main costs are identified as human resources, acquisition of goods and services, and supplies costs, inter alia.

This research offers a vision of sports facilities management in Spain, which is the preferred place of citizens to practice physical activity and sport (Ministry of Education, Culture and Sport, 2015). Specifically, it offers relevant information on economic and management indicators about Spanish sports facilities, which can serve as a reference point for managers and private sports facilities owners, and also for public administrations in sports facilities projects under administrative concession regime. Thereby, the study aims to find out the possible differences between economic and management indicators on Spanish sports facilities, depending on whether they are publicly or privately owned, and according to their business model: administrative licenses, private low-cost, private non-low-cost. For that purpose, the following variables of sports facilities management were analyzed: surface area; number of users (monthly average); income from quota; extraordinary income; total income; average monthly quota and monthly income per customer.

Two hypotheses were proposed:

- Hypothesis A): there are significant differences between public and private sports facilities in the variables analyzed: surface area, number of members, income from quotas, extraordinary income, total income, average monthly quota and monthly income per customer.

- Hypothesis B): there are significant differences between sports facilities according to the business model (public under administrative license, private low-cost, private non-low- 
cost) in the analyzed variables: surface area, number of members, income from quotas, extraordinary income, total income, average monthly quota and monthly income per customer.

\section{Method}

This descriptive and cross-sectional study aims to discover possible differences in the management and exploitation of Spanish sports facilities according to whether they are publicly or privately owned, and according to their business model (administrative licenses, private low-cost, private non-low-cost). For it, it differentiates between sports facilities depending on whether they are publicly or privately owned. In addition, it also classifies them according to their business model, in relation to the price of the monthly fee for the services offered. This or similar classification is used in other studies. This or similar classification is used in other studies (Cereijo, et al., 2019; García-Fernández, Gálvez-Ruiz, Vélez-Colon, Ortega-Gutiérrez \& Fernández-Gavira, 2018). Therefore, sports facilities can be classified as public sports facilities under administrative license; private low-cost sports facilities (with a maximum monthly price of 21.99 euros + VAT), and private non-low-cost sports facilities (with a monthly price of more than 21.99 euros + VAT).

The variables analysed are the sports facilities's surface area, the number of members, the incomes from members' monthly quota, the incomes from extraordinary or complementary services (personal training, physiotherapy, aesthetics, short courses, etc.), total incomes, average monthly user's quota, and the average income per customer.

The scope of the study included the 4435 Spanish sports facilities (IHRSA, 2016). A simple random probability sampling method was performed. With a $95.5 \%$ confidence interval, $50 \%$ population variance and $5 \%$ sample error, the final representative sample of the study required 354 sports facilities. But a final sample of 384 sports facilities was achieved. About those sports facilities, 149 were public (under administrative license), 123 were private low-cost and 112 were private non-low-cost. The 384 sports facilities sampled were geographically distributed throughout the Spanish autonomous communities, except for autonomous cities Ceuta and Melilla, and autonomous community of La Rioja.

Data were collected by a questionnaire survey (MAS Servicios Integrales, 2015), already used in another study (Santacruz, Clemente, Jiménez \& Jiménez-Beatty, in press) adapted for this research, with face-to-face interviews with sports facilities directors or managers, with the exception of sports facilities located in the Canary Islands and the Balearic Islands where the questionnaire was completed by phone. Specific elements were selected from the questionnaire to create this research. The questionnaire validation had 3 phases (Soriano, 2014). First, the research objectives were determined and the one-dimensional study construct was defined. Secondly, validation was carried out based on expert judgment. The team of experts consisted in 6 people with previous experience managing sports facilities as well as in the research of sports facilities management. And thirdly, following the team of expert's recommendations, a pilot test of the questionnaire was carried out by 20 directors or mana- gers of sports facilities in the Community of Madrid, which corroborated the suitability of their questions. The fieldwork was carried out between May and October 2017.

\section{Statistical analysis}

The statistical analysis was performed using the SPSS v.23 programme (SPSS Inc., EE.UU). We employed descriptive and inferential statistical tests. The descriptive statistics found frequency data such as mean and typical deviations.

As for the inferential statistics, to check how normal the distributions were, we used the Kolmogorov-Smirnov test (Smirnov, 1948). Since all the variables were distributed normally, we used as out inferential test the Student T-test (Student, 1908) for independent samples together with a oneway ANOVA test to analyse the relation between the variables. As a post hoc test we chose the Bonferroni test (Miller, 1966), applying the criterion of statistical significance, $p<.05$.

\section{Results}

The results (see Table 1) showed how the averages differ between the seven items analyzed. In most variables studied, the scores were higher in public sports facilities than in private ones (surface area, number of users, income from quotas, extraordinary income, total income). Only in the variables monthly income per customer and average monthly rate, private sports facilities achieved higher average scores than public ones.

In 2016, the average monthly fee was 30.3 euros plus VAT in private sports facilities, and 26.5 euros plus VAT in public ones. The average income per customer was 36.9 euros plus VAT in private sports facilities and 31.4 euros plus VAT in public sports facilities.

\begin{tabular}{|c|c|c|c|c|c|}
\hline & $\begin{array}{c}\text { Centre } \\
\text { Management }\end{array}$ & $\mathrm{N}$ & Average & $\begin{array}{c}\text { Typical } \\
\text { Deviation } \\
\end{array}$ & $\begin{array}{c}\text { Typical error of } \\
\text { the average }\end{array}$ \\
\hline \multirow{2}{*}{ Surface area } & Public & 114 & 5302.76 & 3611.92 & 338.29 \\
\hline & Private & 171 & 2131.59 & 1509.46 & 115.43 \\
\hline \multirow{2}{*}{$\mathrm{N}^{\circ}$ Users } & Public & 121 & 4743.59 & 1970.77 & 179.16 \\
\hline & Private & 178 & 2297.28 & 1059.49 & 79.41 \\
\hline \multirow{2}{*}{ Income from quotas } & Public & 124 & 1436071.19 & 587411.43 & 52751.10 \\
\hline & Private & 178 & 787773.54 & 569717.89 & 42702.16 \\
\hline \multirow{2}{*}{ Extraordinary income } & Public & 122 & 294077.39 & 241358.60 & 21851.58 \\
\hline & Private & 138 & 241604.06 & 425605.69 & 36229.96 \\
\hline \multirow{2}{*}{ Total income } & $\begin{array}{l}\text { Public } \\
\end{array}$ & 124 & 1698392.15 & 779404.74 & 69992.61 \\
\hline & Private & 178 & 975084.32 & 790658.01 & 59262.32 \\
\hline \multirow{2}{*}{ Monthly income per customer } & Public & 121 & 31.44 & 12.40 & 1.13 \\
\hline & Private & 178 & 36.87 & 25.43 & 1.91 \\
\hline \multirow{2}{*}{ Average monthly quota } & Public & 121 & 26.47 & 8.65 & .79 \\
\hline & Private & 178 & 30.32 & 18.36 & 1.38 \\
\hline
\end{tabular}

Once conformity with the Kolmogorov-Smirnov normality criterion for large samples ( $>100$ individuals) was confirmed, we conducted a Levene's, or variance homogeneity, test, which yielded significant differences between variances for all items (Table 2). Then we performed the Student's t-test for independent samples, with a view to finding out whether there were any statistically significant differences between public and private sports facilities in Spain. Table 2 shows that such differences occurred in relation to surface area $\mathrm{t}$ $(283)=10226, p=.00)$; number of members $(\mathrm{t}(297)=13878, p=$ $.00)$; income from quotas $(\mathrm{t}(300)=9605, p=.00)$; total income $(\mathrm{t}(300)=7867, p=.00)$; monthly income per customer $(\mathrm{t}(297)=$ $-2180, p=.03)$; and average monthly quota $(\mathrm{t}(297)=-2149, p=$ $.03)$. 
Table 2.

\begin{tabular}{|c|c|c|c|c|c|c|c|c|c|c|}
\hline & & \multicolumn{5}{|c|}{$\begin{array}{c}\text { Levene's equal } \\
\text { variance test }\end{array}$} & \multicolumn{4}{|c|}{ Equal means t-test } \\
\hline & & \multirow[t]{2}{*}{ F } & \multirow[t]{2}{*}{ Sig. } & \multirow[t]{2}{*}{$\mathrm{T}$} & \multirow[t]{2}{*}{ gl } & \multirow{2}{*}{ Sig. (bil.) } & \multirow{2}{*}{$\begin{array}{c}\text { Means } \\
\text { differences }\end{array}$} & \multirow{2}{*}{$\begin{array}{l}\text { Difference } \\
\text { type error }\end{array}$} & \multicolumn{2}{|c|}{$\begin{array}{l}95 \% \text { Confidence Interval } \\
\text { for difference } \\
\end{array}$} \\
\hline & & & & & & & & & Below & Above \\
\hline \multirow{2}{*}{ Surface area } & $\begin{array}{l}\text { Assuming } \\
\text { equal variances }\end{array}$ & 68.81 & .000 & 10.23 & 283 & .000 & 3171.17 & 310.11 & 2560.76 & 3781.59 \\
\hline & $\begin{array}{l}\text { Not assuming } \\
\text { equal variances }\end{array}$ & & & 8.87 & 139.59 & .000 & 3171.17 & 357.44 & 2464.48 & 3877.87 \\
\hline \multirow{2}{*}{ Users } & $\begin{array}{l}\text { Assuming } \\
\text { equal variances }\end{array}$ & 49.02 & .000 & 13.88 & 297 & .000 & 2446.31 & 176.27 & 2099.41 & 2793.22 \\
\hline & $\begin{array}{l}\text { Not assuming } \\
\text { equal variances }\end{array}$ & & & 12.48 & 167.40 & .000 & 2446.31 & 195.97 & 2059.42 & 2833.201 \\
\hline \multirow{2}{*}{ Income from quota } & $\begin{array}{l}\text { Assuming } \\
\text { equal variances }\end{array}$ & .75 & .387 & 9.61 & 300 & .000 & 648297.64 & 67497.38 & 515469.34 & 781125.94 \\
\hline & $\begin{array}{l}\text { Not assuming } \\
\text { equal variances }\end{array}$ & & & 9.55 & 259.57 & .000 & 648297.64 & 67868.65 & 514654.40 & 781940.88 \\
\hline \multirow{2}{*}{$\begin{array}{l}\text { Extraordinary } \\
\text { income }\end{array}$} & $\begin{array}{l}\text { Assuming } \\
\text { equal variances }\end{array}$ & 13.21 & .000 & 1.20 & 258 & .231 & 52473.33 & 43673.09 & -33527.78 & 138474.43 \\
\hline & $\begin{array}{l}\text { Not assuming } \\
\text { equal variances }\end{array}$ & & & 1.24 & 221.60 & .216 & 52473.33 & 42309.59 & -30907.33 & 135853.98 \\
\hline \multirow{2}{*}{ Total income } & $\begin{array}{l}\text { Assuming } \\
\text { equal variances }\end{array}$ & 2.57 & .110 & 7.87 & 300 & .000 & 723307.83 & 91947.59 & 542363.89 & 904251.76 \\
\hline & $\begin{array}{l}\text { Not assuming } \\
\text { equal variances }\end{array}$ & & & 7.89 & 267.16 & .000 & 723307.83 & 91711.44 & 542738.69 & 903876.96 \\
\hline \multirow{2}{*}{$\begin{array}{l}\text { Monthly income } \\
\text { per customer }\end{array}$} & $\begin{array}{l}\text { Assuming } \\
\text { equal variances }\end{array}$ & 88.15 & .000 & -2.18 & 297 & .030 & -5.43 & 2.49 & -10.34 & -.5283 \\
\hline & $\begin{array}{l}\text { Not assuming } \\
\text { equal variances }\end{array}$ & & & -2.45 & 273.18 & .015 & -5.43 & 2.21 & -9.79 & -1.07 \\
\hline \multirow{2}{*}{$\begin{array}{l}\text { Average monthly } \\
\text { quota }\end{array}$} & $\begin{array}{l}\text { Assuming } \\
\text { equal variances }\end{array}$ & 57.99 & .000 & -2.15 & 297 & .032 & -3.85 & 1.79 & -7.37 & -.32 \\
\hline & $\begin{array}{l}\text { Not assuming } \\
\text { equal variances }\end{array}$ & & & -2.43 & 269.15 & .016 & -3.85 & 1.59 & -6.97 & -.73 \\
\hline
\end{tabular}

between administrative license and low-cost sports facilities $(p=.000)$, and between administrative license and private non-low cost centres $(p=.00)$; extraordinary income between administrative license and low-cost sports facilities $(p=.00)$, and between administrative license and private non-low cost centres $(p=.00)$; total income between administrative license and low-cost sports facilities $(p=.00)$, and between administrative license and private non-low cost centres $(p=.00)$; monthly income per customer between administrative license and low-cost sports facilities $(p=.00)$, and between administrative license and private non-low cost centres $(p=.00)$; and average monthly quota between administrative license and low-cost sports facilities $(p=.000)$, and between administrative license and private non-low cost centres $(p=.000)$.
To find out whether there were statistically significant differences between sports facilities as a function of their business model (administrative license, private low-cost or private non-low-cost), a one-way analysis of variance (ANOVA) was realized. Table 3 shows statistically significant differences for all variables: surface area $\mathrm{F}(2)=55979, p=.00$; number of members $\mathrm{F}(2)=99982, p=.00$; income from quotas $\mathrm{F}(2)=84342, p=.00$; extraordinary income $\mathrm{F}(2)=36458, p=$ .00 ; total income $\mathrm{F}(2)=81120, p=.00$; monthly income per customer $\mathrm{F}(2)=192527, p=.00$; and average monthly quota $\mathrm{F}(2)=164520, p=.00$.

Table 3.

Differences in Spanish sports facilities management and exploitation as per ownership (public or private) and business model

\begin{tabular}{|c|c|c|c|c|c|c|}
\hline & & Sum of squares & $\begin{array}{c}\begin{array}{c}\text { Degrees of } \\
\text { freedom }\end{array} \\
\end{array}$ & Root mean square & $\mathrm{F}$ & Sig. \\
\hline \multirow[t]{3}{*}{ Surface area } & Inter-groups & 724499497.41 & 2 & 362249748.71 & 55.98 & .000 \\
\hline & Intra-groups & 1824884964.57 & 282 & 6471223.28 & & \\
\hline & Total & 2549384461.99 & 284 & & & \\
\hline \multirow{3}{*}{$\mathrm{N}^{\circ}$ Users } & Inter-groups & 441823800.08 & 2 & 220911900.01 & 99.98 & .000 \\
\hline & Intra-groups & 654015236.61 & 296 & 2209510.93 & & \\
\hline & Total & 1095839036.68 & 298 & & & \\
\hline \multirow{3}{*}{$\begin{array}{l}\text { Income from } \\
\text { quotas }\end{array}$} & Inter-groups & 47108162460766.67 & 2 & 23554081230383.33 & 84.34 & .000 \\
\hline & Intra-groups & 83500986690679.25 & 299 & 279267514015.65 & & \\
\hline & Total & 130609149151445.90 & 301 & & & \\
\hline \multirow{3}{*}{$\begin{array}{l}\text { Extraordinary } \\
\text { income }\end{array}$} & Inter-groups & 7081937528531.88 & 2 & 3540968764265.92 & 36.46 & .000 \\
\hline & Intra-groups & 24961297356958.66 & 257 & 97125670649.65 & & \\
\hline & Total & 32043234885490.54 & 259 & & & \\
\hline \multirow{3}{*}{ Total income } & Inter-groups & 78652460466546.31 & 2 & 39326230233273.16 & 81.12 & .000 \\
\hline & Intra-groups & 144953119665601.34 & 299 & 484793042359.87 & & \\
\hline & Total & 223605580132147.66 & 301 & & & \\
\hline \multirow{3}{*}{$\begin{array}{l}\text { Monthly } \\
\text { income per } \\
\text { customer }\end{array}$} & Inter-groups & 76355.22 & 2 & 38177.61 & 192.53 & .000 \\
\hline & Intra-groups & 58695.92 & 296 & 198.29 & & \\
\hline & Total & 135051.12 & 298 & & & \\
\hline & Inter-groups & 36708.89 & 2 & 18354.44 & 164.52 & .000 \\
\hline monthly & Intra-groups & 33022.88 & 296 & 111.56 & & \\
\hline quota & Total & 69731.77 & 298 & & & \\
\hline
\end{tabular}

To verify between which type of sports facilities business models (administrative license, low-cost or private) there were statistically significant differences, we carried out the post hoc Bonferroni test. As Table 4 shows, this test yielded statistically significant differences for the following variables: surface area between administrative license and lowcost sports facilities $(p=.00)$, and between administrative license and private non-low cost centres $(p=.00)$; the number of users between administrative license and low-cost sports facilities $(p=.00)$, and between administrative license and private non-low cost centres $(p=.00)$; income from quotas
Table 4.

Multiple analysis of Spanish public and private sports facilities as per business model

\begin{tabular}{|c|c|c|c|c|c|}
\hline Dependent variable & $\begin{array}{c}\text { (I)Type of } \\
\text { sports facilitie }\end{array}$ & $\begin{array}{l}\text { (J)Type of sports } \\
\text { facilitie }\end{array}$ & $\begin{array}{c}\text { Average } \\
\text { differences }\end{array}$ & $\begin{array}{l}\text { Typical } \\
\text { error }\end{array}$ & Sig. \\
\hline \multirow{6}{*}{ Surface area } & \multirow{2}{*}{ Concession } & Low Cost & 3590.16 & 354.41 & .000 \\
\hline & & Private & 2659.69 & 375.24 & .000 \\
\hline & \multirow{2}{*}{ Low Cost } & Concesión & -3590.16 & 354.41 & .000 \\
\hline & & Private & -930.47 & 391.01 & .054 \\
\hline & \multirow{2}{*}{ Private } & Concession & -2659.69 & 375.24 & .000 \\
\hline & & Low Cost & 930.47 & 391.01 & .054 \\
\hline \multirow{6}{*}{$\mathrm{N}^{\circ}$ Users } & \multirow{2}{*}{ Concession } & Low Cost & 2214.07 & 204.38 & .000 \\
\hline & & Private & 2706.21 & 211.10 & .000 \\
\hline & \multirow{2}{*}{ Low Cost } & Concession & -2214.07 & 204.37 & .000 \\
\hline & & Private & 492.14 & 223.18 & .085 \\
\hline & \multirow{2}{*}{ Private } & Concession & -2706.21 & 211.10 & .000 \\
\hline & & Low Cost & -492.14 & 223.18 & .085 \\
\hline \multirow{6}{*}{ Income from quotas } & \multirow{2}{*}{ Concession } & Low Cost & 935155.05 & 72270.94 & .000 \\
\hline & & Private & 327290.54 & 74677.78 & .000 \\
\hline & \multirow{2}{*}{ Low Cost } & Concession & -935155.05 & 72270.94 & .000 \\
\hline & & Private & -607864.51 & 79344.47 & .000 \\
\hline & \multirow{2}{*}{ Private } & Concession & -327290.54 & 74677.779 & .000 \\
\hline & & Low Cost & 607864.51 & 79344.47 & .000 \\
\hline \multirow{6}{*}{ Extraordinary income } & \multirow{2}{*}{ Concession } & Low Cost & 263527.92 & 46115.08 & .000 \\
\hline & & Private & -184557.22 & 47857.63 & .000 \\
\hline & \multirow{2}{*}{ Low Cost } & Concession & -263527.92 & 46115.08 & .000 \\
\hline & & Private & -448085.13 & 53148.19 & .000 \\
\hline & \multirow{2}{*}{ Private } & Concession & 184557.22 & 47857.63 & .000 \\
\hline & & Low Cost & 448085.13 & 53148.19 & .000 \\
\hline \multirow{6}{*}{ Total income } & \multirow{2}{*}{ Concession } & Low Cost & 1173751.79 & 95220.77 & .000 \\
\hline & & Private & 219239.57 & 98391.91 & .080 \\
\hline & \multirow{2}{*}{ Low Cost } & Concession & -1173751.79 & 95220.77 & .000 \\
\hline & & Private & -954512.22 & 104540.51 & .000 \\
\hline & \multirow{2}{*}{ Private } & Concession & -219239.57 & 98391.91 & .080 \\
\hline & & Low Cost & 954512.22 & 104540.51 & .000 \\
\hline \multirow{6}{*}{ Monthly income per customer } & \multirow{2}{*}{ Concession } & Low Cost & 13.87 & 1.94 & .000 \\
\hline & & Private & -27.01 & 1.99 & .000 \\
\hline & \multirow{2}{*}{ Low cost } & Concession & -13.87 & 1.94 & .000 \\
\hline & & Private & -40.91 & 2.11 & .000 \\
\hline & \multirow{2}{*}{ Private } & Concession & 27.04 & 1.99 & .000 \\
\hline & & Low Cost & 40.91 & 2.11 & .000 \\
\hline \multirow{6}{*}{ Average monthly quota } & Concession & Low Cost & 9.53 & 1.45 & .000 \\
\hline & & Private & -18.82 & 1.50 & .000 \\
\hline & Jow Cost & Concession & -9.53 & 1.45 & .000 \\
\hline & Low Cost & Private & -28.35 & 1.59 & .000 \\
\hline & Private & Concession & 18.82 & 1.50 & .000 \\
\hline & & Low Cost & 28.35 & 1.59 & .000 \\
\hline
\end{tabular}

Discussion and conclusions

Although research related to the object of this study is scarce, it is possible to relate certain global indicators to some of the variables we have analysed. In this regard, IHRSA (2016) found that, with 4435 sports facilities, Spain comes fourth in Europe for number of centres, after Germany $(8684$ centres), Italy (7500 centres) and the United Kingdom (6728 centres). Worldwide, the country with most sports facilities is the United States, with 36540.

As for the number of members of sports facilities, Spain is fifth in Europe, with 5060000 members, behind Germany 
(10080000), United Kingdom(9700000), France (5460000) and Italy (5250000). As for turnover, according to IHRSA(2017), total income in 2016 for all Spain's sports facilities amounted to 2402341760 •, the fifth largest amount in Europe after the United Kingdom (6103896104€), Germany (5588128000•), France $(2727670400 €)$ and Italy $(2451030400 €)$. Europe Active and Deloitte (2019), estimated that the total income in 2018 was $2235000000 \bullet$ in Spain.

As for rates of physical activity and sports in European Union (EU) countries, Ríos, Monleón-Getino, Cubedo and Martín (2016) found in their study of 26788 European citizens (data provided by the European Commission) that the highest rates of habitual physical and sporting activity were to be found in Sweden (0.42) Finland (0.40) and Denmark (0.25). Countries such as Spain (-0.03), Italy (-0.17) Portugal (-0.15) and, particularly, Greece (-0.3) were below the average for EU countries (-0.01).

Focusing on the variables studied, in relation to the variable surface area, the comparison of our study results with those recorded by the Swimming Clubs in Catalonia (MAS, 2017) shows how the swimming clubs of Catalonia have an average area of $10393 \mathrm{~m}^{2}$, of which $5193 \mathrm{~m}^{2}$ are allocated to sports courts and space, while according to our study the average for public sports facilities is $5303 \mathrm{~m}^{2}$, a value that falls to $2132 \mathrm{~m}^{2}$ for private sports facilities. The fact that Catalonia's swimming clubs include at least one multipurpose pool among their sports courts and spaces could explain why this is the group of sports facilities with the largest surface area.

As for number of members, Catalonia's swimming clubs have an average of 7050 members, which is again higher that the average for public sports facilities (4744 members) and private ones (2297 members). Factors such as a great sports offer in Catalonian swimming clubs and a great feeling of belonging to a club would explain these differences that push them towards their club.

Regarding income from quotas, in 2016 Catalonia's swimming clubs registered an average of 2402935 , far above those for public (1436071 €) and private (787773 €) sports facilities. These differences seem logical because swimming clubs have more members than the sports facilities showed in this study. Similarly, it happens in the variable of extraordinary receipts, because this indicator is related to the number of members, so the greater the number of members, the greater the probability that there will be an increase in extraordinary income from services provided in addition to those included in the monthly fee. Another study, Martínez and González-Sastre (2016) found that low-cost sports facilities had between $216000 \bullet$ and $444000 €$ total income in 2015 . Sánchez-Oliver and Grimaldi-Puyana (2017) found important differences between micro, small, medium and large companies. Those data would corroborate the idea that as the area of sports facilities increases, it is more likely that there will be more members and, wherefore, more income.

Finally, as far as average monthly quota and average monthly income are concerned, the results obtained are similar, with Catalonian swimming clubs recording an average monthly quota of $30.5 €$, which is very close to that private sports facilities but rather above the equivalent amount for public ones $(26.5 €)$. As for average monthly income,
Catalonian swimming clubs obtained $43.28 €$, which is higher than the values recorded for public $(31.44 €)$ and private (36.87 €) sports facilities. These results may be logical because in Spain, in many cases, the price of public services for sports facilities is established by the public administration, which tries to make them accessible to the entire population.

The results show that public sports facilities are larger than private ones. In addition, public sports facilities also have a larger number of members, resulting in higher incomes as well. This fact coincides with the study by Mata (2016).

In conclusion, it can be assumed that there are significant differences between public and private sports facilities in Spain for the management indicators of surface area, number of members, income from quotas, total income, average monthly income and monthly income per customer. But there are no significant differences in the indicator of extraordinary receipts. Therefore, hypothesis A is confirmed in all variables except in the variable of extraordinary income. This information could be of great value to sports facilities managers when drawing up their action plans.

Depending on the business model implanted in each sports facilities (administrative license, non-low-cost private, low-cost private), significant differences in terms of surface area are to be found between administrative license and lowcost models, and between administrative license and nonlow-cost models. The same is true of the number of members variable between administrative license and low-cost models, and between administrative license and non-low-cost models; of the income from quotas variable between administrative license and low-cost models, and between administrative license and non-low-cost models; of the income from courses and extraordinary services variable between administrative license and low-cost models, and between administrative license and non-low-cost models; of the total income variable between private low-cost and administrative license models, and between private low-cost and private non-low-cost models; of the monthly income per customer variable between administrative license and lowcost models, and between administrative license and nonlow-cost models; and of the average monthly quota variable between administrative license and low-cost models, and between administrative license and non-low-cost models. Therefore, hypothesis B is confirmed in all cases, except for the variable surface area between private low-cost and private non-low-cost sports facilities; the variable number of clients between private low-cost and private non-low-cost; and the variable total income between private non-low-cost centers and administrative license sports facilities. This information can be very useful when choosing which business model to implement in some sports facilities, since, for example, strategic decisions related to the services provided are related to the center, or the staking out of a particular niche may be influenced by the monthly quota the members have to pay to enjoy the services offered

Due to the lack of rigorous studies of the object of study of the manuscript, a limitation of the study is that it is a purely descriptive study. Further research is required into the sports facilities sector which will enable them to improve management and exploitation with a view to enhancing the quality of the services they provide to the population. 


\section{References}

Águila, C., Sicilia,A., Muyor, J. M., \& Orta,A. (2009). Cultura posmoderna y perfiles de práctica en los centros deportivos municipales. International Journal of Medicine and Science of Physical Activity and Sport, 9(33), 81-95.

Alberto, C., Hernando, V., \& Fernández, J.A. (1996). Gestión y Dirección de Empresas Deportivas Teoría y Práctica. Madrid: Gymnos.

Algar, R. (2012). 2012 UK low-cost gym sector report. A strategic investigation into a disruptive new segment. United Kingdom: Oxygen consulting.

Aznar, I., Cáceres, M.P., Trujillo, J.M, \& Romero, J.M. (2019) Impact of mobile apps on physical activity: A metaanalysis. Retos, 36, 52-57.

Barros, C., \& Gonçalves, L. (2009). Investigating individual satisfaction in health and fitness training centres. International Journal of Sport Management and Marketing, 5(4), 384-395.

Carrasco, D. (2012). Manual de Procedimiento para la implantación de un sistema de costes

en la Administración Local. Madrid: Federación Española de Municipios y Provincias

Carrasco, D., Buendía, D., Navarro, A., Valencia, M., \& Llorente, V. (2006). La evaluación de la eficiencia de los servicios públicos deportivos a través de modelos de cálculo de costes e indicadores de gestión. Revista Base (Administraçao e Contabilidade) da Unisinos, 3(3), 311320.

Cereijo, L., Gullón, P., Cebrecos, A., Bilal, U., Santacruz, J.A., Badland, H., \& Franco M. (2019). Access to and availability of exercise facilities in Madrid: an equity perspective. Internarional Journal of Healths Geographics, 18(1), 1-10.

Chesbrough, H., \& Rosenbloom, R.S. (2001). The role of the business model in capturing value from innovation: evidence from Xerox Corporation's technology spin-off companies. Industrial \& Corporate Change, 11(3), 529555.

De la Cámara, M.Á. (2015) El sector del fitness en España; análisis del gimnasio lowcost y los centros de electroestimulación integral. SPORT TK Revista Euroamericana de Ciencias del Deporte, 4(2), 47-54.

De la Cámara, M.Á., Valcarce-Torrente, M., \& Veiga, O. (2020). National Survey of Fitness Trends in Spain for 2020. Retos, 37, 427-433.

Dorado, A. (2006). La gestión privada en las organizaciones deportivas. In E. Beotas, E. Blanco, J.C. Cubeiro, A, Dorado, L. Gallardo, J. Lozano, D. Marín-Barnuevo, S. Ortega, F.J. Ramírez, A. Senlle, Futuras claves en la gestión de organizaciones deportivas (pp. 103-116). Cuenca: Publicaciones Universidad de Castilla la Mancha.

Estrada-Marcén, N., Sanz, G., Casterad, J., Simón, J., \& Roso, M. (2019). Professional profile of workers in the fitness sector in the city of Zaragoza. Retos, 35, 185-190.

Europe Active \& Deloitte (2019). European Health \& Fitness Market Report 2018. London: Deloitte.

Gambau, V. (2002) Estudio de la organización de los clubes deportivos en Galicia: un análisis empírico (Tesis doctoral). Universidad de A Coruña, Facultad de Medicina,
España.

García, A., \& Froment, F. (2018). Benefits of physical activity on self-esteem and quality of life of older people. Retos, 33, 3-9.

García-Fernández, J., Gálvez-Ruiz, P., Vélez-Colon, L., Ortega-Gutiérrez, J., \& Fernández-Gavira, J. (2018). Exploring fitness centre consumer loyalty: differences of non-profit and low-cost business models in Spain. Economic Research-Ekonomska Istra-ivanja, 31(1), 1042-1058.

García, M., \& Llopis, R. (2006). Posmodernidad y Deporte: Entre la Individualización y la Masificación. Encuesta hábitos deportivos de los españoles 2005. Madrid: Consejo Superior de Deportes.

García, M., \& Llopis, R. (2011). Ideal democrático y bienestar personal. Encuesta sobre los hábitos deportivos en España 2010. Madrid: Consejo Superior de Deportes.

García, J., Cepeda, G., \& Martín, D. (2012). La satisfacción de clientes y su relación con la percepción de calidad en Centro de Fitness: utilización de la escala CALIDFIT. Revista de Psicología del Deporte, 21(2), 309-319.

Giles-Corti, B., \& Donovan, R.J. (2003). Relative influence of individual, social environmental and physical environmental correlates of walking. American Journal of Public Health, 93(9), 1583-1589.

Gómez, S., \& Opazo, M. (2006), Sport organizations structure: Trends and evolution in the research field. En 14th EASM Congress (European Association of Sport Management). Nicosia: EASM.

Haro-González, M., Pérez-Ordas, R., Leyton-Román, M., Caamaño-Guadix,A., \& Nuviala,A. (2018). Groups of users in the women sports market. Retos, 34, 123-127.

Hsueh, Y.S., \& Su, J.M. (2013). The relationship among service quality and satisfaction of customers in fitness centers located in Southern Taiwan. Life Science Journal, 10(4), 2613-2618.

International Health \& Sportsclub Association IHRSA(2016). Global Report. Boston: IHRSA.

International Health \& Sportsclub Association IHRSA(2017). IHRSA Global Report. Boston: IHRSA.

Kaplan, R., \& Norton, D. (2008) Cuadro de Mando Integral [Integral scorecard]. Barcelona: Gestion 2000. $2^{\text {a }}$ edición.

Law 30/2007 (30 October), regarding Public Sector Contracts.

Li, F., Fisher, K., Brownson, R., \& Bosworth, M. (2005). Multilevel modelling of built environment characteristics related to neighbourhood walking activity in older adults. Journal of Epidemiology and Community Health, 59(7), 558-564.

Magretta J. (2002). Why Business Models Matter. Harvard business review, 80, 86-92.

Martínez, I., \& González-Sastre, B. (2016). El mercado del fitness en España: Un estudio exploratorio sobre el perfil económico del segmento low-cost. Cultura, Ciencia y Deporte, 11(3), 197-206.

Martínez, J.A., \& Martínez, L. (2010). La medición de la satisfacción del consumidor de servicios deportivos a través de la lógica borrosa. Revista de Psicología del Deporte, 19(1), 41-48.

Martínez-Tur, V., González, P., Ramos, J., Tordera, N., Peiró, J., \& Rodríguez, I. (1995) La distinción entre organizaciones públicas y privadas: diferencias en la gestión de instala- 
ciones deportivas. Journal of work and organizational psychology, 11(32), 27-50.

MAS Servicios Integrales (2015). Informe Global de las Instalaciones Deportivas Españolas 2014. Madrid: Mas Servicios Integrales.

MAS Servicios Integrales (2017). Cierre de cuentas de los clubes de natación de Cataluña 2016. Madrid: MAS Servicios Integrales.

Mata, E. (2016). Factores de gestión asociados al éxito o al fracaso económico de las empresas que gestionan instalaciones deportivas en la Comunidad Valenciana (Tesis Doctoral). Universidad Católica de Valencia San Vicente Mártir, Factultad de Ciencias de la Actividad Física y del Deporte, España.

Miller, R.G. (1966). Simultaneous statistical inference. New York: McGraw Hill.

Ministry of Education, Culture and Sport (2015). Encuesta de Hábitos Deportivos en España. Retrieved from https:/ /www.csd.gob.es/es/encuesta-de-habitos-deportivos

Orzanco-Garralda, MR., Guillén, F., Sainz, L., Redín, M., De la Rosa, R., \& Aguinaga-Ontoso, I. (2016). Influencia de las características urbanísticas en el nivel de actividad física en las personas de 18 a 65 años de edad del área metropolitana de Pamplona. Revista Española Salud Pública, 90, 1-10.

Osterwalder A., Pigneur Y., \& Tucci C. (2005). Clarifying Business Models: origins, Present, and Clarifying Business Models: Origins, Present, and Future of the Concept. Communications of the Association for Information Systems, 16(1), 751- 775.

París, F. (2003). La Planificación Estratégica en las Organizaciones Deportivas. Barcelona: Editorial Paidotribo.

Pascual, C. Regidor, E., Astasio, P., Ortega, P., Navarro, \& Domínguez, P. (2007). The association of current and sustained area-based adverse socioeconomic environment with physical inactivity. Social Science and Medicine, 65(3), 454-466.

Porter, M. (2009). Estrategia Competitiva: técnicas para el análisis de la empresa y sus competidores. Madrid: Pirámide.

Rial, J., Varela, J., Rial,A., \& Real, E. (2010). Modelización y medida de la calidad percibida en centros deportivos: la escala QSport-10. Revista Internacional de Ciencias del Deporte, 6(18), 57-73.

Ríos, D., Monleón-Getino, T., Cubedo. M., \& Ríos, M. (2016). A Graphical Classification of European Countries According to Physical Activity Level of Its Citizens. Open Access Library Journal, 3(12), 1-11.
Sanchez-Oliver,A., \& Grimaldi-Puyana, M. (2017). Las pymes de gestión de actividades de los gimnasios y de gestión de instalaciones deportivas en España. Podium Sport, Leisure and Tourisme Review, 6(3), 30-45.

Smirnov, N.V. (1948). Table for estimating the goodness of fit of empirical distributions. Ann. Math. Stat, 19(2), 279281.

Santacruz, J.A., Clemente, A.L., Jiménez, V. \& Jiménez-Beatty, J.E. (in press). Swimming sports clubs of Catalonia in the current competitive context of the sports facilities sector. SPORT TK: Revista Euroamericana de Ciencias del Deporte, $10(1)$.

Sociological Research Office of the Basque Government (2017). Deporte y actividad física. Retrieved from http:// www.euskadi.eus/contenidos/documentacion/o_17tef4/ es_def/adjuntos/17tef4.pdf

Soriano, A.M. (2014). Diseño y validación de instrumentos de medición. Diá-logos, 14, 19-40.

Stahl, T., Rütten, A., Nutbeam, D., Bauman, A., Kannas, L., Abel. T., ... Van der Zee, J. (2001). The importance of the social environment for physically active lifestyle-results from an international study. Social Science and Medicine, 52(1), 1-10.

Student (1908). The probable error of a mean. Biometrika, 125.

Tsitskari, E.I., \& Tsitskari, A. (2013). Does satisfaction affect a member's psychological commitment to a fitness center? Journal of Physical Education and Sport, 13(4), 522527. doi: 10.7752 /jpes.2013.04082

Ulseth, A.L. (2004). Social integration in modern sport: Commercial fitness centres and voluntary sport clubs. European Sport Management Quarterly, 4(2), 95-115.

Valls, J.F. (2010). Reinventar el modelo de negocio para vender más barato. Aproximación al análisis comparado de las estrategias Low Cost. Revista de Contabilidad y Dirección, 11, 11-24.

Van Lenthe, F.J.; Brug, J., \& Mackenbach, J.P. (2005). Neighbourhood inequalities in physical inactivity: the role of neighbourhood attractiveness, proximity to local centres and safety in the Netherlands. Social Scince and Medicine, 60(4), 763-775.

Veiga, O., Valcarce, M., King,A., \& De la Cámara, M.A. (2018). National Survey of Fitness Trends in Spain for 2018. Retos, 33, 279-285.

Veiga, O., Valcarce-Torrente, M., King, A., \& De la Cámara, M.A. (2019). National Survey of Fitness Trends in Spain for 2019. Retos, 35, 341-347.

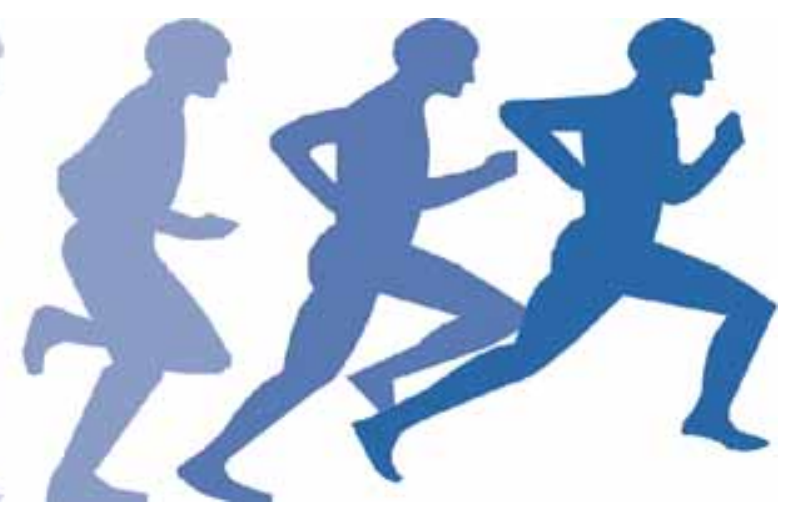

